\title{
Post-traumatic symptoms in the staff of a mental health inpatient unit after the suicide of a patient: a case report in Chile
}

\section{Síntomas postraumáticos en funcionarios de un servicio de hospitalización psiquiátrica luego del suicidio de un paciente: reporte de un caso en Chile}

\author{
Rodrigo Andrés Figueroa* \\ Tomás León \\ Department of Psychiatry, Pontificia Universidad Católica de Chile School of Medicine \\ Richard Sorensen \\ United States Air Force \\ (Rec.: agosto de 2016 - Acept.: diciembre de 2016)
}

\begin{abstract}
BACKGROUND: Multiple studies have shown that the suicide of a patient can produce posttraumatic and depressive symptoms among the mental health care providers, who typically have high levels of baseline burnout. OBJECTIVES: To measure posttraumatic, depressive and burnout symptoms in the staff of an inpatient psychiatric unit after the suicide of a patient. METHODS: Two months after the suicide all the employees were invited to answer, anonymously, the Posttraumatic Check-List (PCL), the Beck Depression Inventory (BDI), and the Maslach Burnout Inventory (MBI), for measuring posttraumatic, depressive, and burnout symptoms, respectively. RESULTS: Over $80 \%$ of the staff participated. A total of $17.1 \%$ had probable PTSD, $19.5 \%$ probable major depression, $24.4 \%$ and $14.6 \%$ high levels of emotional exhaustion and depersonalization, respectively, and $24.4 \%$ low levels of professional accomplishment. The group consisting of nurses, paramedic technicians, and nursing assistants ("nursing staff") had PTSD significantly greater than other workers $(p<.001)$. CONCLUSIONS: Suicide in a psychiatric ward can produce posttraumatic and depressive symptoms among the staff, as high as another kind of traumas. The impact may be greater on the nursing staff. It is essential that organizations involved in the provision or teaching of mental health care incorporate this reality into their agenda, to prevent, mitigate and respond better to this phenomenon.
\end{abstract}

Keywords: suicide, inpatients, hospitals, psychiatric, health personnel.

\section{Resumen}

ANTECEDENTES: Múltiples estudios han mostrado que el suicidio de un paciente puede producir síntomas postraumáticos y depresivos en el personal de salud mental, quienes además presentan altos niveles de burnout basal. OBJETIVOS: Medir síntomas postraumáticos, depresivos y de burnout en los funcionarios de una unidad de hospitalización psiquiátrica luego del suicidio de un paciente. MÉTODOS: Dos meses después del suicidio, todos los funcionarios fueron invitados a contestar anónimamente el Postraumatic Check-List (PCL), el Inventario de Depresión de Beck (BDI), y el Inventario de Burnout de Maslach (MBI), para medir síntomas postraumáticos, depresivos, y de burnout, respectivamente. RESULTADOS: Más del $80 \%$ de los funcionarios contestaron los cuestionarios. Un total de 17,1\% tenía probable Trastorno de Estrés Postraumático, 19,5\% probable depresión mayor, $24,4 \%$ y $14,6 \%$ altos niveles de agotamiento emocional y despersonalización, respectivamente, y 24,4\% bajos niveles de satisfacción profesional. El grupo compuesto por enfermeras universitarias, técnicos paramédicos, y asistentes de enfermería ("personal de enfermería") tuvo síntomas de Trastorno de Estrés Postraumático significativamente mayores que otros funcionarios $(p<.001)$. CONCLUSIONES: El suicidio en una unidad de hospitalización psiquiátrica puede producir tantos síntomas postraumáticos y depresivos en los funcionarios de salud como otros tipos de traumas. El impacto podría ser mayor en el personal de enfermería. Es indispensable que las organizaciones involucradas en la provisión o enseñanza de salud mental incorporen esta realidad en sus agendas, para prevenir, mitigar y responder mejor a este fenómeno.

Palabras clave: suicidio, pacientes hospitalizados, hospitales, psiquiátricos, personal de salud.

\footnotetext{
* Correspondence to: Rodrigo A. Figueroa, Department of Psychiatry, Pontificia Universidad Católica de Chile School of Medicine. Diagonal Paraguay 362, Of. 544, Santiago, Chile. E-mail: rfiguerc@uc.cl
} 


\section{Introduction}

Of all the events that mental health staff experience during their career, the suicide of a patient is one of the most intense on both a professional and personal level. However, this does not seem to be an exceptionally rare situation, but rather the opposite. Some 22$39 \%$ of psychologists, $33 \%$ of social workers, $55 \%$ of psychiatry nurses, and up to $82 \%$ of psychiatrists have lost one or more patient due to suicide throughout their career (Cappelli et al., 1995; Chemtob, Bauer, Hamada, Pelowski \& Muraoka, 1989; Chemtob, Hamada, Bauer, Kinney \& Torigoe, 1988; Cryan, Kelly \& McCaffrey, 1995; Dewar, Eagles, Klein, Gray \& Alexander, 2000; Grad \& Michel, 2005; Horn, 1995; Howard, 2001; Jacobson, Ting, Sanders \& Harrington, 2004; Takahashi et al., 2011). This situation affects not only trained professionals but also those still in training, where the personal and vocational impact could be even greater. For example, it has been reported that $11-17 \%$ of the psychology interns have experienced the loss of a patient by suicide (Kleespies, 1993). In the United States, 54 heads of psychiatry residency programs were surveyed and found that each resident experiences the suicide of an average of 1.44 patients per year (Tsai, Moran, Shoemaker, \& Bradley, 2012). Note that most suicides experienced by psychiatry residents in the U.S. occur during the first year of their training (Brown, 1987).

Moreover, the risk of suicide of a hospitalized patient is significantly higher in psychiatry services compared to others hospital units. The international literature describes that the suicide rate in hospitalized psychiatric patients reaches 250 per 100,000 admissions, compared to other services where it reaches 1.8 per 100,000 (Martelli, Awad \& Hardy, 2010). That is, the risk of suicide in a psychiatry service is 139 times higher than in other hospital units. Among the most important risk factors for suicide in a psychiatric unit are male gender, age under 40 years, previous suicide attempt, family history of suicide, recently attempted suicide, schizophrenia, mood disorder, alcohol use, administrative hospitalization, living alone, and fugue (Martelli et al., 2010; Pieters, De Gucht, Joos \& De Heyn, 2003).

Since the risk of inpatient suicide is higher in psychiatric wards, it is important to analyze its impact on the staff of these services along with their baseline emotional status. It has been seen that the suicide of a patient generates changes in health care workers both at their work and personal life. Significant among psychiatrists are feelings of professional failure, questions about their expertise, concerns about legal repercussions and changes in their professional practice (Campbell \& Fahy, 2002; Grad \& Michel, 2005; Grad, Zavasnik \& Groleger, 1997; Hendin, Lipschitz, Maltsberger, Haas \& Wynecoop, 2000; Henry, Séguin \& Drouin, 2008; Horn, 1994). However, it has been shown that to the extent that physicians acquire greater professional experience, the guilt, low self-esteem and social withdrawal experienced after the suicide of a patient decreases (Chemtob et al., 1988). For residents, on the other hand, in addition to generating pain, guilt, fear and frustration (Scocco, Toffol, Pilotto \& Pertile, 2012), the suicide of a patient can produce fear of criticism from their supervisors (Farberow, 2005). It has been reported that psychiatry residents can have involuntary recalls of the event up to one year after the event, especially on the anniversary of the suicide (Lafayette \& Stern, 2004). One study showed that the suicide of a patient might have a mild to moderate impact on clinical behavior, especially in the first month after the event. For example, psychiatrists showed higher levels of anxiety in treating high-risk patients and were more likely to hospitalize, monitor and pay more attention to risk factors for suicide. A small fraction might even consider changing their careers (Gulfi, Castelli Dransart, Heeb \& Gutjahr, 2010),

A clinical study showed that a quarter of the psychiatrists who experienced the suicide of a patient presented high levels of posttraumatic stress symptoms, especially if the suicide had occurred during their residency (Ruskin, Sakinofsky, Bagby, Dickens \& Sousa, 2004). In another study, $13.7 \%$ of a sample of psychiatry nurses who had experienced the suicide of a patient had probable PTSD. Only $15.8 \%$ reported having had access to a post-event mental health program (Takahashi et al., 2011), which may have increased their symptoms, among other factors, as a consequence of low perceived social support (Brewin, Andrews \& Valentine, 2000).

As mentioned above, clinical psychiatry involves high levels of stress that have been associated with baseline burnout and psychiatric disorders. This stress affects not only psychiatrists but the whole mental health team. It has been reported that psychiatrists, compared with other medical specialists, have higher rates of burnout (Hawton, Clements, Sakarovitch, Simkin \& Deeks, 2001; Kumar, 2011; Kumar, 2007). A Finnish study of 1,115 physicians found that psychiatrists have a significantly increased risk of smoking, alcohol abuse, obesity and physical inactivity. Also, physicians who are dedicated to mental health are more likely to have a chronic illness, both physical and psychological, as well as an increased risk of antidepressant use and missed work days because of depression (Virtanen et al., 2012). The picture is similar in other mental health care professionals. For example, in a study of 180 nurses from different services, $40 \%$ of those stationed in mental health units had burnout, a figure significantly higher than the observed in those assigned to other services (Sahraian, Fazelzadeh, Mehdizadeh \& Toobaee, 2008).

The psychiatry ward of a private clinic in Santiago, 
Chile, has 20 short-stay beds. The clinic is part of the health care network of a major medicine school of the country. There are one staff psychiatrist and one psychiatry resident on-site 24 hours-a-day. There is also a nursing team comprised of 1-3 nurses, 2-3 paramedic technicians, and 1-2 nursing assistants, with some variability depending on whether it is a business day or a weekend. A group of two clinical psychologists and two occupational therapists also work in the ward. The nurses, paramedic technicians and nursing assistants are the most exposed to day-to-day contact with inpatients because they constantly stay on the nursing station, which is located within the ward.

In January 2012, one of the inpatients committed suicide in its room. It occurred despite all the safety measures that had been taken according to his clinical condition, including in-room surveillance cameras and regular visits by staff. When the patient was found dead in his room, 10 minutes had elapsed since the last time he had been visited. During that period the patient entered the bathroom and hanged himself with a cord pulled from the seam of his sweatpants. Immediate basic and advanced life support were unsuccessful.

In the days after the suicide, the psychiatry service organized many meetings to address the situation, both with the team who had been on duty at the time of the suicide, as well as the whole psychiatry ward staff. These meetings were intended to inform the staff about the evolving situation, normalize emotional reactions, resolve any apprehensions and doubts, and open a space for psychological support for those in need. All the members of staff were offered free-ofcharge professional mental health care in the event they felt a need for it.

Although the emotional and vocational impact of a suicide of inpatients on mental health staff has been reported in the international literature, we could not find such reports in Latin American, were cultural issues could modify the findings. For this reason, we decided to conduct this study, aimed to evaluate the posttraumatic stress, depressive, and burnout symptoms on the staff after this suicide. We hypothesized that the prevalence of probable PTSD and depression would be greater compared to the general population and equivalent to other groups affected by traumatic experiences. We also hypothesized that burnout levels would be comparable to those observed in other populations of mental health staff.

\section{Methods}

\section{Sample}

All the members of staff of the psychiatric ward were invited to participate in the study on a confidential and voluntary basis. For this, two months after the suicide of the patient an invitation was sent via email which ex- plained the objectives of the research. They were also contacted personally by the chief of staff, as well as the principal investigator, to resolve any concerns they may have had. We made it clear that the investigation would be completely anonymous and that no demographic data would be collected that could reveal the identity of the respondents. All the staff had the opportunity to know their results anonymously and authorized the research and the use of their data for this publication through an informed consent document.

\section{Instruments}

PTSD symptoms were measured with the Spanish version of the Posttraumatic Stress Disorder Checklist-Specific Version (PCL-S) (Blanchard, Jones-Alexander, Buckley \& Forneris, 1996; Marshall, 2004; Miles, Marshall \& Schell, 2008; Orlando \& Marshall, 2002). The PCL is a 17-item self-administered questionnaire that assesses the levels of discomfort that produce the PTSD symptoms in the last month on a Likert scale of 1-5 points, where the total score is obtained summing the score of all the items. The minimum score is 17 points, and the maximum is 85 . The psychometric properties of the Spanish version have shown to be equivalent to those of the English version in a sub-population of victims of blunt or penetrating injuries admitted to emergency units in Los Angeles, USA (Marshall, 2004; Miles et al., 2008; Orlando \& Marshall, 2002). Also, it showed good psychometric properties in the Chilean general population affected by the earthquake of February 27th, 2010 (Vera-Villarroel, Zych, Celis-Atenas, Córdova-Rubio \& Buela-Casal, 2011), with an internal consistency (Cronbach's alpha) of $0.89 \%$. The English version has shown a correlation of 0.92 with the Clinician Administered PTSD Scale (CAPS) (Blanchard et al., 1996), currently considered the gold standard for PTSD diagnosis. To detect cases of "probable PTSD," we decided to use a cutoff score of 44 or more, as suggested by Blanchard, who reported a sensitivity of 0.94 , a specificity of 0.86 , and an overall diagnostic accuracy of 0.90 (Blanchard et al., 1996).

Depressive symptoms were measured with the 1979 version of the Beck Depression Inventory (BDI) (Beck, Rush, Shaw \& Emery, 1979), adapted to Spanish by Sanz and Vazquez (Sanz \& Vázquez, 1998). It is a 21item, self-administered questionnaire, with four sentences each, which assess the presence of depressive phenomena during the last week. It has an internal consistency of 0.76 to 0.95 , with a test-retest reliability of 0.8 , and a Person's correlation of 0.55 to 0.73 with the Hamilton Depression Rating Scale (Edwards et al., 1984). For detection of cases of "probable depression," we used a cutoff of 13 because it allowed a sensitivity of $100 \%$, specificity of $99 \%$, positive predictive value of 0.72 and negative predictive value of 1.0 in Spain (Lasa, Ayuso-Mateos, Vázquez-Barquero, Díez-Manrique \& Dowrick, 2000). In Chile, Ruiz, Silva \& Miranda (2001) 
showed that compared to a structured clinical diagnosis made by a psychiatrist, the BDI has a sensitivity of $81.8 \%$, a specificity of $39.7 \%$, a positive predictive value of $34.0 \%$, and a negative predictive value of $85.2 \%$.

Burnout symptoms were assessed with the Maslach Burnout Inventory (MBI) (Maslach \& Jackson, 1981), adapted to Spanish by Moreno-Jiménez, Oliver-Jiménez \& Aragoneses (1991). It consists of a 22item questionnaire in which the person must respond on a Likert scale of 0-6 points on how often they experiment different phenomena related to burnout. MBI consists of three subscales: emotional exhaustion (EE), depersonalization (DP) and personal accomplishment (PA). The analysis is by dimension, having considered the recommended ranges of "low" burnout $(A E \leq 18$, $\mathrm{DP} \leq 5, \mathrm{PA} \geq 40$ ), "medium" (AE = 19-26, DP = 6-9, RP = 34-39) or "high" burnout ( $A E \geq 27, \mathrm{DP} \geq 10, \mathrm{RP} \leq 33)$.

\section{Assessment}

All the scales were applied remotely through the Internet with Google Forms, allowing more privacy. The application was conducted approximately two months after the suicide of the patient.

\section{Statistical Analysis}

There was no missing data. We did not trim data. We calculated descriptive statistics for all the variables according to the position of the staff members and overall. The existence of a significant mean difference between positions was estimated with one-way ANOVA, and Bonferroni's test for multiple comparisons was used to compare means of specific pairs of jobs. We also calculated bivariate correlations between each variable. Several multiple linear regressions were modeled with the PCL and the BDI as targets (method: enter; stepping method criteria: use probability of $F$ with entry $=.05$ and removal $=.10)$. As an explanatory factor, we tried several alternatives of dichotomization of the variable "position." In the results, we just present the best-fitted models, but we can send other models upon request to interested readers. After finding a significant association of being a nurse, paramedic technician, or nursing assistant with the PCL, we aggregated these positions into a new, comprised category named "nursing staff," to analyze its association with posttraumatic, depressive, or burnout symptoms using Bonferroni's test for multiple comparisons. In all the calculations, we used $p$ values $<0.05$ as a criterion of statistical significance. All statistical analyses were performed using SPSS version 20.

\section{Results}

Overall, forty-one out of 49 (83.7\%) of the staff responded the survey. All the nurses $(\mathrm{N}=6)$, psychologists $(\mathrm{N}=2)$, occupational therapists $(\mathrm{N}=2)$, and nursing assistants $(\mathrm{N}=5)$ participated in the study. Only
$70 \%$ of the psychiatrists (7/10), $78.6 \%$ of the psychiatry residents (11/14), and $80 \%$ of the paramedic technicians $(8 / 10)$ participated.

In the whole sample, the mean (standard deviation) of the PCL was 28.3 (12.1) (Table 1, Figure 1). Seven (17.1\%) participants had probable PTSD. There was a significant difference between the mean of the PCL scores according to position ( $p=.03$ ), but there were no significant differences between specific pairs of jobs after adjusting for multiple comparisons (Table 2). There was a positive, significant correlation between the $P C L$ and the BDI, EE, and DP, and a negative, significant correlation between the PCL and PA (Table 3). Three variables showed an independent, significant association with PTSD symptoms. These were a higher BDI score $(p<.01)$, a lower professional accomplishment ( $p$ $<.02)$, and being nurse, paramedic technician, or nursing assistant $(p<.01)$ (Table 4$)$.

Table 1. Mean and standard deviations of variables

\begin{tabular}{lccc}
\hline & N & Mean & Std. Deviation \\
\hline PCL & 41 & 28,29 & 12,117 \\
BDI & 41 & 6,66 & 6,155 \\
EE & 41 & 21,54 & 10,684 \\
\hline DP & 41 & 5,80 & 4,202 \\
PA & 41 & 38,68 & 5,998 \\
Valid N (listwise) & 41 & & \\
\hline
\end{tabular}

Regarding depressive symptoms, the mean (standard deviation) BDI score was 6.7 (6.2). Eight (19.5\%) participants had probable major depression. There were no significant differences of mean BDI scores between staff positions. The BDI was positively and significantly correlated to EE and DP, and negatively and significantly correlated to PA. Two variables showed a significant and independent association with depressive symptoms. These were a higher score on the PCL $(p<$ .01) and a higher score on EE $(p<.01)$ (Table 5).

The mean (standard deviation) of EE, DP, and PA scores were 21.5 (10.7), 5.8 (4.2), and 38.7 (6.0), respectively. Ten participants $(24.4 \%)$ had high levels of EE, six $(14.6 \%)$ high levels of DP and ten (24.4\%) low levels of PA. There were no statistically significant differences in EE, DP nor PA scores between staff positions. EE significantly correlated to DP and PA, and DP was significantly correlated to PA.

Being a member of the nursing staff was significantly ( $p<.001)$ associated with posttraumatic, but not depressive or burnout symptoms (Figure 2).

\section{Discussion}

In our sample, approximately 1 in 6 members of staff of the psychiatric ward developed probable PTSD two 
Post-tRaumatic SYMPTOMS IN THE STAFF OF A MENTAL HEALTH INPATIENT UNIT AFTER THE SUICIDE OF A PATIENT:

$$
\text { A CASE REPORT IN CHILE }
$$

Table 2. ANOVA

\begin{tabular}{|c|c|c|c|c|c|c|}
\hline & & Sum of Squares & df & Mean Square & $\mathrm{F}$ & Sig. \\
\hline \multirow{3}{*}{ PCL } & $\begin{array}{l}\text { Between } \\
\text { Groups }\end{array}$ & 1869,585 & 6 & 311,598 & 2,647 & 0,032 \\
\hline & Within Groups & 4002,903 & 34 & 117,732 & & \\
\hline & Total & 5872,488 & 40 & & & \\
\hline \multirow{3}{*}{ BDI } & $\begin{array}{l}\text { Between } \\
\text { Groups }\end{array}$ & 265,120 & 6 & 44,187 & 1,202 & 0,329 \\
\hline & Within Groups & 1250,100 & 34 & 36,768 & & \\
\hline & Total & 1515,220 & 40 & & & \\
\hline \multirow{3}{*}{$\mathrm{EE}$} & $\begin{array}{l}\text { Between } \\
\text { Groups }\end{array}$ & 706,060 & 6 & 117,677 & 1,036 & 0,419 \\
\hline & Within Groups & 3860,136 & 34 & 113,533 & & \\
\hline & Total & 4566,195 & 40 & & & \\
\hline \multirow{3}{*}{$\mathrm{DP}$} & $\begin{array}{l}\text { Between } \\
\text { Groups }\end{array}$ & 66,003 & 6 & 11,001 & 0,584 & 0,741 \\
\hline & Within Groups & 640,436 & 34 & 18,836 & & \\
\hline & Total & 706,439 & 40 & & & \\
\hline \multirow{3}{*}{ PA } & $\begin{array}{l}\text { Between } \\
\text { Groups }\end{array}$ & 119,845 & 6 & 19,974 & 0,515 & 0,793 \\
\hline & Within Groups & 1319,033 & 34 & 38,795 & & \\
\hline & Total & 1438,878 & 40 & & & \\
\hline
\end{tabular}

Figure 1. Mean score of variables. Error bars represent $95 \% \mathrm{Cl}$.

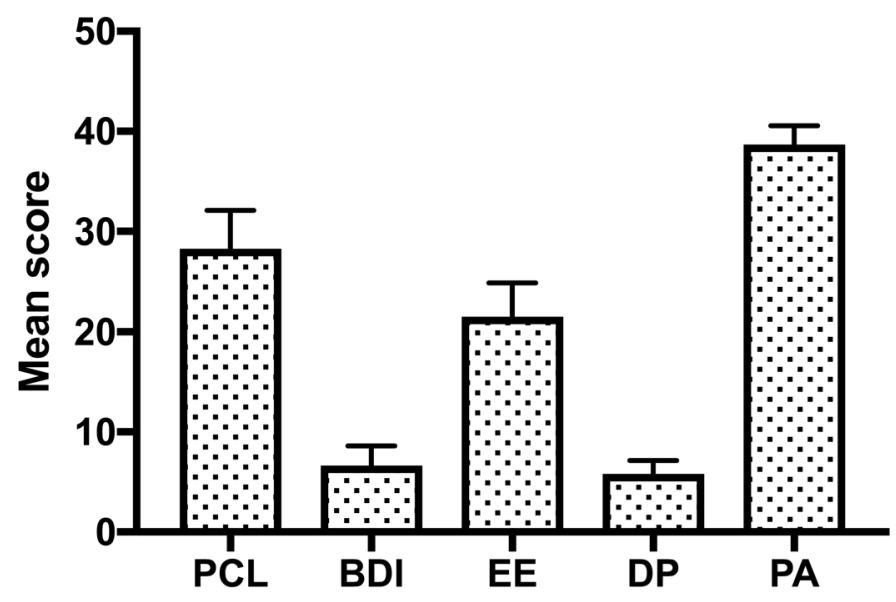

months after the suicide of a patient. This incidence is similar to what has been observed after other traumatic events in the general population (Kessler, Sonnega, Bromet, Hughes \& Nelson, 1995; Norris et al., 2003; Zlotnick et al., 2006). In Chile, $2.4 \%$ of the general population has had PTSD in the last 12 months (Vicente et al., 2006), so our sample had a PTSD prevalence greater than usual. Our results suggest that the patient's suicide had an emotional impact equivalent to other trau- matic events in this specific population, as reported in other samples affected by the same kind of events (Takahashi et al., 2011). Note the significant association between PTSD symptoms and major depression, consistent with other studies (Kessler et al., 1995).

Several explanations may account for the higher symptoms of PTSD in the group of nurses, paramedics technicians, and nursing assistants, including a higher ex- 
Tabla 3. Correlations.

\begin{tabular}{|c|c|c|c|c|c|c|}
\hline & & PCL & BDI & $\mathrm{EE}$ & $\mathrm{DP}$ & PA \\
\hline & Pearson Correlation & 1 & ,699** & ,356* & ,329* &,$- 498 * *$ \\
\hline \multirow[t]{3}{*}{ PCL } & Sig. (2-tailed) & & 0,000 & 0,022 & 0,036 & 0,001 \\
\hline & $\mathrm{N}$ & 41 & 41 & 41 & 41 & 41 \\
\hline & Pearson Correlation & ,699** & 1 & ,609** & $482^{* *}$ &,$- 384^{*}$ \\
\hline \multirow[t]{3}{*}{ BDI } & Sig. (2-tailed) & 0,000 & & 0,000 & 0,001 & 0,013 \\
\hline & $\mathrm{N}$ & 41 & 41 & 41 & 41 & 41 \\
\hline & Pearson Correlation & ,356* &, $609 * *$ & 1 & $671^{* *}$ &,$- 352^{*}$ \\
\hline \multirow[t]{3}{*}{$\mathrm{EE}$} & Sig. (2-tailed) & 0,022 & 0,000 & & 0,000 & 0,024 \\
\hline & $\mathrm{N}$ & 41 & 41 & 41 & 41 & 41 \\
\hline & Pearson Correlation & ,329* &, $482^{* *}$ &, $671^{* *}$ & 1 &,$- 508^{* *}$ \\
\hline \multirow[t]{3}{*}{$\mathrm{DP}$} & Sig. (2-tailed) & 0,036 & 0,001 & 0,000 & & 0,001 \\
\hline & $\mathrm{N}$ & 41 & 41 & 41 & 41 & 41 \\
\hline & Pearson Correlation &,$- 498 * *$ &,$- 384^{*}$ &,$- 352^{*}$ &,$- 508^{* *}$ & 1 \\
\hline \multirow[t]{2}{*}{ PA } & Sig. (2-tailed) & 0,001 & 0,013 & 0,024 & 0,001 & \\
\hline & $\mathrm{N}$ & 41 & 41 & 41 & 41 & 41 \\
\hline
\end{tabular}

**. Correlation is significant at the 0.01 level (2-tailed).

*. Correlation is significant at the 0.05 level (2-tailed).

Table 4. Multiple linear regression.

\begin{tabular}{|c|c|c|c|c|c|c|c|}
\hline & \multicolumn{2}{|c|}{ Unstandardized Coefficients } & \multirow{2}{*}{$\begin{array}{c}\begin{array}{c}\text { Standardized } \\
\text { Coefficients }\end{array} \\
\text { Beta }\end{array}$} & \multirow[b]{2}{*}{$\mathrm{t}$} & \multirow[b]{2}{*}{ Sig. } & \multicolumn{2}{|c|}{$95.0 \%$ Confidence Interval for B } \\
\hline & $\mathrm{B}$ & Std. Error & & & & Lower Bound & Upper Bound \\
\hline (Constant) & 43,538 & 10,651 & & 4,088 & 0,000 & 21,915 & 65,161 \\
\hline BDI & 1,071 & 0,272 & 0,544 & 3,946 & 0,000 & 0,520 & 1,623 \\
\hline EE & 0,000 & 0,176 & 0,000 & $-0,001$ & 0,999 & $-0,356$ & 0,356 \\
\hline DP & $-0,390$ & 0,422 & $-0,135$ & $-0,924$ & 0,362 & $-1,247$ & 0,467 \\
\hline PA & $-0,612$ & 0,237 & $-0,303$ & $-2,576$ & 0,014 & $-1,094$ & $-0,130$ \\
\hline Nursing staff & 7,668 & 2,614 & 0,320 & 2,933 & 0,006 & 2,361 & 12,975 \\
\hline
\end{tabular}

Figure 2. Mean score of variables according to staff group. Error bars represent $95 \% \mathrm{Cl}$.

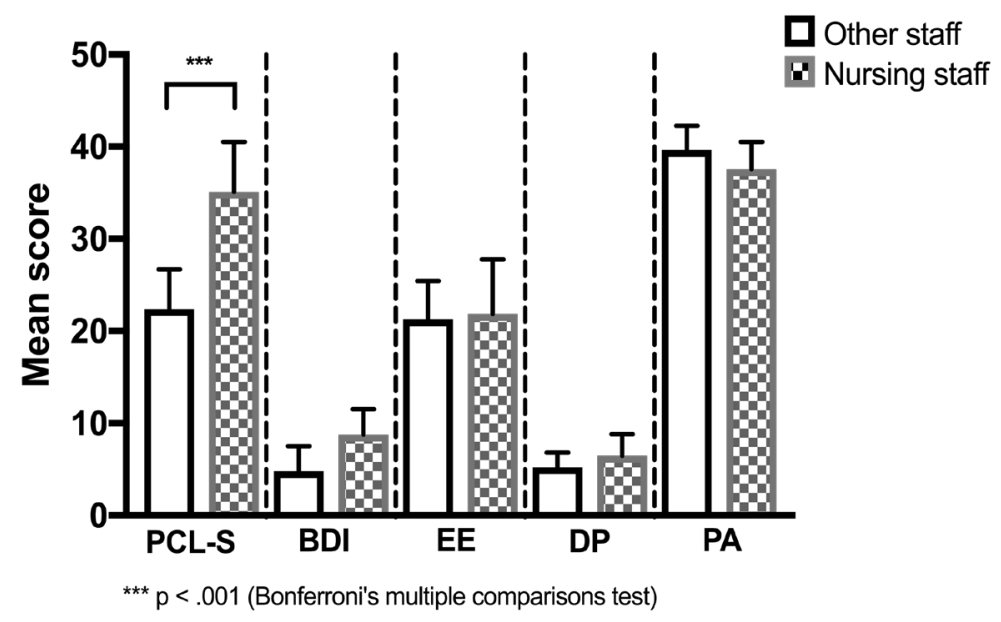


Post-traumatic Symptoms IN THE STAFF OF A MENTAL HEALTH INPATIENT UNIT AFTER THE SUICIDE OF A PATIENT: A CASE REPORT IN CHILE

Table 5. Multiple linear regression.

\begin{tabular}{|c|c|c|c|c|c|c|c|}
\hline & \multicolumn{2}{|c|}{ Unstandardized Coefficients } & \multirow{2}{*}{$\begin{array}{c}\begin{array}{c}\text { Standardized } \\
\text { Coefficients }\end{array} \\
\text { Beta }\end{array}$} & \multirow[b]{2}{*}{$t$} & \multirow[b]{2}{*}{ Sig. } & \multicolumn{2}{|c|}{$95.0 \%$ Confidence Interval for B } \\
\hline & $\mathrm{B}$ & Std. Error & & & & Lower Bound & Upper Bound \\
\hline (Constant) & $-10,022$ & 6,336 & & $-1,582$ & 0,122 & $-22,871$ & 2,828 \\
\hline PCL & 0,293 & 0,060 & 0,577 & 4,890 & 0,000 & 0,172 & 0,415 \\
\hline EE & 0,219 & 0,079 & 0,380 & 2,764 & 0,009 & 0,058 & 0,379 \\
\hline DP & 0,111 & 0,214 & 0,076 & 0,519 & 0,607 & $-0,323$ & 0,546 \\
\hline PA & 0,078 & 0,130 & 0,076 & 0,601 & 0,552 & $-0,186$ & 0,343 \\
\hline
\end{tabular}

a. Dependent Variable: BDI

posure to rumors and gossip about the suicide and its consequences, lower levels of control over their workflow, and larger demands from patients on a day-today basis.

Rumors are currently circulating stories or reports of uncertain or doubtful truth. Rumors are ubiquitous after suicides and spread faster among people who share the same spaces of conversation such as colleagues, neighbors, or even "friends" in social media (Liu, Xu \& Tourassi, 2015; Luxton, June \& Fairall, 2012; Robinson et al., 2016). In the inpatient unit studied, the nursing staff is assembled in teams that share the same shift schedule, having a larger time of connivance on duty than other workers. It has been shown that circulation of rumors may promote negative social interactions, jeopardizing the salutogenic effect of social support after traumatic events and increasing symptoms of distress, including post-traumatic symptoms (Bonanno, Brewin, Kaniasty \& Greca, 2010; Bromet, 2014; Witteveen et al., 2007). In such a way, it may be the case that our sample of nursing staff may have been more exposed to rumors than other employees, increasing their PTSD symptoms.

According to Karasek's job demands-control model, the level of autonomy of the worker over how and when she perform her tasks buffers the impact of job demands on work strain (Landsbergis, 1988). A higher level of stress is a risk factor for PTSD (Brewin et al., 2000), so it is plausible that jobs with low baseline control (e.g. air traffic control) and consequently higher levels of stress may facilitate the development of PTSD after traumatic events. In the inpatient psychiatry unit, control over tasks is lower in nursing staff compared to other workers, given the immediacy of demands they face (e.g. emergency physical restraint). Lower control could lead to higher baseline levels of stress, and consequently a larger incidence of PTSD. Moreover, nursing staff faces more daily demands from patients than other members of the psychiatric ward staff. Given their permanent presence in the nursing station, they are constantly committed to attend requests and demands from patients and relatives. Both higher demand and lower control of the nursing staff may have contributed to their higher incidence of PTSD after the suicide of the patient.
A total of $19.5 \%$ of our sample had BDI scores suggesting major depression, more than three times the national prevalence, which reach $5.7 \%$ in the last 12 months (Vicente et al., 2006). This larger prevalence could be a consequence of the index event, but it could also correspond to a baseline condition before the event, given the higher prevalence of mental disorders observed in other samples of mental health care providers compared to the general population (Virtanen et al., 2012). A longitudinal study is essential to clarify this possibility. The significant correlation between symptoms of major depression and emotional exhaustion suggests that burnout may be correlated with major depression.

Regarding symptoms of burnout, we found that approximately $24.4 \%, 14.6 \%$, and $24.4 \%$ of respondents had high levels of emotional exhaustion, depersonalization, and low levels of professional accomplishment, respectively. This figure is relatively similar to that reported by Avendaño, Bustos, Espinoza, García \& Pierart (2009), were $20 \%$ and $22 \%$ of mental health staff of a psychiatric department in a public hospital in Chile had high levels of emotional exhaustion and depersonalization, respectively, and $26 \%$ low personal accomplishment. Órdenes (2004), in a sample of members of the staff of a children's hospital in Chile, found that $31 \%$ of them suffered burnout. Another study conducted on 91 emergency nurses from the XIII Region in Chile showed that $24.2 \%$ and $42.1 \%$ had high levels of emotional exhaustion and depersonalization, respectively, and $23.9 \%$ low personal accomplishment (Melita-Rodríguez, Cruz-Pedreros \& Merino, 2008). Hernández (2003) reported symptoms of burnout in $30 \%$ of a sample of health care staff of the primary and secondary care in Chile. Note that high emotional exhaustion has been reported in only $1.5 \%$ of a sample of university professors in Chile's V Region (Quass, 2006).

Besides burnout, being a member of a mental health team has been associated with mental and physical health problems (Carpenter, Swerdlow \& Fear, 1997; Hawton et al., 2001; Kumar, 2007). As mentioned above, it has been reported that mental health professionals have more psychopathology indicators than other specialists (Virtanen et al., 2012). Although the reason for this is not clear, it has been speculated to be related to several factors. These includes a closer emotional 
bond with patients, less cooperation of some of them compared to other specialties, a permanent risk of suicidality, a higher prevalence of personality disorders in their patients, and more demanding families and social problems, among other factors (David, Bedford, Wiffen \& Gilleen, 2012; Zanarini, Frankenburg, Hennen \& Silk, 2004). If we also add the possibility that these teams must deal with episodes of high emotional impact, such as self-harm or aggression to others (Martelli et al., 2010), it becomes clear that the mental health staff works in a highly stressful environment that require strong occupational hygiene measures. Given the highest levels of emotional exhaustion among nurses, paramedic technicians, and nursing assistants, our results suggest that this group should be specifically considered in these plans. This is important not only for the benefit of the staff but also for the patients because burnout has been associated with poorer quality of care (Aiken et al., 2012; Leiter, Harvie \& Frizzell, 1998). Institutions should add evidence-based occupational health programs, mental health protection, and permanent crisis mitigation plans in their training and operation agendas, given the high prevalence of these problems in this group.

This study has remarkable strengths from a methodological point of view. First, the high percentage of participation (above $80 \%$ ) suggests that the results are representative of the studied population. Second, we used an anonymous survey where we omitted questions about demographics that may have inhibited the person to answer truthfully because of fear of being punished at work. This increases the likelihood that the information obtained is valid, since the lack of anonymity may distort the answers, especially in workplaces because reasonable concerns of compromising the job (Warner et al., 2011). The cross-sectional nature of this study, however, does not identify causal relationships between variables, particularly depression or burnout, where the instruments we used did not identify precipitating factors. The "S" version of the PCL could mitigate this limitation because it measured PTSD symptoms specifically related to the suicide. Additionally, the population of mental health staff studied is not representative of the reality of the major part of the mental health care staff in Chile. The team we studied works in a private, high-cost hospital, serving a wealthier population of patients with a pattern of psychosocial problems different to that of patients in public hospitals. Although access to economic resources is greater in wealthy patients, facilitating the access to some costly treatments, it is also true that they and their families may be more demanding to the nursing staff, imposing different challenges compared to public hospitals.

\section{References}

Aiken, L., Sermeus, W., Van den Heede, K., Sloane, D., Busse,
R., McKee, M. \& Kutney-Lee, A. (2012). Patient safety, satisfaction, and quality of hospital care: cross sectional surveys of nurses and patients in 12 countries in Europe and the United States. The British Medical Journal, 344, 1-14. doi:10.1136/bmj.e1717

Avendaño, C., Bustos, P., Espinoza, P., García, F. \& Pierart, T. (2009). Burnout y apoyo social en personal del servicio de psiquiatría de un hospital público. Ciencia y Enfermería, 15(2), 55-68. doi:10.4067/S071795532009000200007

Beck, A., Rush, A., Shaw, B. \& Emery, G. (1979). Cognitive therapy of depression (1st ed.). New York: The Guildford Press.

Blanchard, E., Jones-Alexander, J., Buckley, T. \& Forneris, C. (1996). Psychometric properties of the PTSD Checklist (PCL). Behaviour Research and Therapy, 34(8), 669-673. doi:10.1016/0005-7967(96)00033-2

Bonanno, G., Brewin, C., Kaniasty, K. \& Greca, A. (2010). Weighing the costs of disaster consequences, risks, and resilience in individuals, families, and communities. Psychological Science in the Public Interest, 11(1), 1-49. doi:10.1177/1529100610387086

Brewin, C., Andrews, B. \& Valentine, J. (2000). Meta-analysis of risk factors for posttraumatic stress disorder in trauma-exposed adults. Journal of Consulting and Clinical Psychology, 68(5), 748-766. doi:10.1037/0022006X.68.5.748

Bromet, E. (2014). Emotional consequences of nuclear power plant disasters. Health Physics, 106(2), 206-210. doi:10.1097/HP.0000000000000012

Brown, H. (1987). The impact of suicide on therapists in training. Comprehensive Psychiatry, 28(2), 101-112. doi:10.1016/0010-440X(87)90075-7

Campbell, C. \& Fahy, T. (2002). The role of the doctor when a patient commits suicide. Psychiatric Bulletin, 26(2), 44-49. doi:10.1192/pb.26.2.44

Cappelli, M., Clulow, M., Goodman, J., Davidson, S., Feder, S., Baron, P., ... \& McGrath, P. (1995). Identifying depressed and suicidal adolescents in a teen health clinic. Journal of Adolescent Health, 16(1), 64-70. doi:10.1016/1054-139X(94)00076-Q

Carpenter, L., Swerdlow, A. \& Fear, N. (1997). Mortality of doctors in different specialties: findings from a cohort of 20000 NHS hospital consultants. Occupational and Environmental Medicine, 54(6), 388-395. Retrieved from https://www.ncbi.nlm.nih.gov/pmc/articles/ PMC1128798/

Chemtob, C., Bauer, G., Hamada, R., Pelowski, S. \& Muraoka, M. (1989). Patient suicide: Occupational hazard for psychologists and psychiatrists. Professional Psychology: Research and Practice, 20(5), 294-300. doi:10.1037/0735-7028.20.5.294

Chemtob, C., Hamada, R., Bauer, G., Kinney, B. \& Torigoe, R. (1988). Patients' suicides: frequency and impact on psychiatrists. The American Journal of Psychiatry, 145(2), 224-228. doi:10.1176/ajp.145.2.224

Cryan, M., Kelly, P. \& McCaffrey, B. (1995). The experience of patient suicide among Irish psychiatrists. Psychiatric 
Post-tRaumatic SYMPTOMS IN THE STAFF OF A MENTAL HEALTH INPATIENT UNIT AFTER THE SUICIDE OF A PATIENT:

\section{A CASE REPORT IN CHILE}

Bulletin, 19(1), 4-7. doi:10.1192/pb.19.1.4

David, A., Bedford, N., Wiffen, B. \& Gilleen, J. (2012). Failures of metacognition and lack of insight in neuropsychiatric disorders. Philosophical Transactions $B, 367(1594)$, 1379-1390. doi:10.1098/rstb.2012.0002

Dewar, I., Eagles, J., Klein, S., Gray, N. \& Alexander, D. (2000). Psychiatric trainees' experiences of, and reactions to patient suicide. Psychiatric Bulletin, 24(1), 20-23. doi:10.1192/pb.24.1.20

Edwards, B., Lambert, M., Moran, P., McCully, T., Smith, K. \& Ellingson, A. (1984). A meta-analytic comparison of the Beck Depression Inventory and the Hamilton Rating Scale for Depression as measures of treatment outcome. British Journal of Clinical Psychology, 23(2), 93-99. doi:10.1111/j.2044-8260.1984.tb00632

Farberow, N. (2005). The mental health professional as suicide survivor. Clinical Neuropsychiatry: Journal of Treatment Evaluation, 2(1), 13-20. Retrieved from http://www.clinicalneuropsychiatry.org/pdf/03 farberow.pdf

Grad, O. \& Michel, K. (2005). Therapists as client suicide survivors. Therapeutic and Legal Issues for Therapists Who Have Survived a Client Suicide: Breaking the Silence. New York: Routledge.

Grad, O., Zavasnik, A. \& Groleger, U. (1997). Suicide of a patient: gender differences in bereavement reactions of therapists. Suicide and Life-Threatening Behavior, 27(4), 379-386. doi:10.1111/j.1943-278X.1997.tb00517.x

Gulfi, A., Castelli Dransart, D., Heeb, J. \& Gutjahr, E. (2010). The impact of patient suicide on the professional reactions and practices of mental health caregivers and social workers. Crisis, 31(4), 202-210. doi:10.1027/00275910/a000027

Hawton, K., Clements, A., Sakarovitch, C., Simkin, S. \& Deeks, J. (2001). Suicide in doctors: a study of risk according to gender, seniority and specialty in medical practitioners in England and Wales, 1979-1995. Journal of Epidemiology \& Community Health, 55(5), 296-300. doi:10.1136/jech.55.5.296

Hendin, H., Lipschitz, A., Maltsberger, J., Haas, A. \& Wynecoop, S. (2000). Therapists' reactions to patients' suicides. The American Journal of Psychiatry, 157(12), 2022-2027. doi:10.1176/appi.ajp.157.12.2022

Henry, M., Séguin, M. \& Drouin, S. (2008). L'impact du suicide d'un patient chez des professionnels en santé mentale. Frontières, 21(1), 53-63. doi:10.7202/037874ar

Hernández, J. (2003). Estrés y Burnout en profesionales de la salud de los niveles primario y secundario de atención. Revista Cubana de Salud Pública, 29(2), 103110. Retrieved from http://ref.scielo.org/47mptm

Horn, P. (1994). Therapists' psychological adaptation to client suicide. Psychotherapy: Theory, Research, Practice, Training, 31(1), 190-195. doi:10.1037/0033-3204.31.1.190

Horn, P. (1995). Therapists' psychological adaptation to client suicidal behavior. Dissertation Abstracts International: Section B: The Sciences and Engineering, 56(5-B).

Howard, E. (2001). Incidence and impact of client suicide on health service providers in psychology. Dissertation Abstracts International: Section B: The Sciences and Engineering, 61(9-B).

Jacobson, J., Ting, L., Sanders, S. \& Harrington, D. (2004). Prevalence of and Reactions to Fatal and Nonfatal Client Suicidal Behavior: A National Study of Mental Health Social Workers. OMEGA - Journal of Death and Dying, 49(3), 237-248. doi:10.2190/HPKQ-T700-EPQL$58 \mathrm{JQ}$

Kessler, R., Sonnega, A., Bromet, E., Hughes, M. \& Nelson, C. (1995). Posttraumatic stress disorder in the National Comorbidity Survey. Archives of General Psychiatry, 52(12), 1048-1060. doi:10.1001/archpsyc.1995.03950240066012

Kleespies, P. (1993). Suicide in mental disorder. Suicide and Life-Threatening Behavior, 23(1), 67-73. doi:10.1111/ j.1943-278X.1993.tb00281.x

Kumar, S. (2007). Burnout in psychiatrists. World Psychiatry, 6(3), 186-189. Retrieved from https://www.ncbi.nlm. nih.gov/pmc/articles/PMC2175073/

Kumar, S. (2011). Burnout and psychiatrists: what do we know and where to from here? Epidemiology and Psychiatric Sciences, 20(4), 295-301. doi:10.1017/ S204579601100059X

Lafayette, J. \& Stern, T. (2004). The impact of a patient's suicide on psychiatric trainees: a case study and review of the literature. Harvard Review of Psychiatry, 12(1), 49-55. doi:10.1080/10673220490279152

Landsbergis, P. (1988). Occupational stress among health care workers: A test of the job demands-control model. Journal of Organizational Behavior, 9(3), 217-239. doi:10.1002/job.4030090303

Lasa, L., Ayuso-Mateos, J., Vázquez-Barquero, J., Díez-Manrique, F. \& Dowrick, C. (2000). The use of the Beck Depression Inventory to screen for depression in the general population: a preliminary analysis. Journal of Affective Disorders, 57(1-3), 261-265. doi:10.1016/ S0165-0327(99)00088-9

Leiter, M. P., Harvie, P. \& Frizzell, C. (1998). The correspondence of patient satisfaction and nurse burnout. Social Science \& Medicine, 47(10), 1611-1617. doi:10.1016/ S0277-9536(98)00207-X

Liu, Y., Xu, S. \& Tourassi, G. (2015). Detecting Rumors Through Modeling Information Propagation Networks in a Social Media Environment. Social Computing, Behavioral-Cultural Modeling, and Prediction, 90(21), 121-130. doi:10.1007/978-3-319-16268-3 13

Luxton, D., June, J. \& Fairall, J. (2012). Social media and suicide: a public health perspective. American Journal of Public Health, 102(Suppl. 2), S195-S200. doi:10.2105/ AJPH.2011.300608

Marshall, G. (2004). Posttraumatic Stress Disorder Symptom Checklist: factor structure and English-Spanish measurement invariance. Journal of Traumatic Stress, 17(3), 223-230. doi:10.1023/B:JOTS.0000029265.56982.86

Martelli, C., Awad, H. \& Hardy, P. (2010). [In-patients suicide: epidemiology and prevention]. Encephale, 36(Suppl. 2), D83-D91. doi:10.1016/j.encep.2009.06.011 
Maslach, C. \& Jackson, S. (1981). The measurement of experienced burnout. Journal of Organizational Behavior, 2(2), 99-113. doi:10.1002/job.4030020205

Melita-Rodríguez, A., Cruz-Pedreros, M. \& Merino, J. (2008). Burnout en profesionales de enfermería que trabajan en centros asistenciales de la octava región, Chile. Ciencia y Enfermería, 14(2), 75-85. doi:10.4067/S071795532008000200010

Miles, J., Marshall, G. \& Schell, T. (2008). Spanish and English versions of the PTSD Checklist-Civilian version (PCL-C): testing for differential item functioning. Journal of Traumatic Stress, 21(4), 369-376. doi:10.1002/ jts.20349

Moreno-Jiménez, B., Oliver-Hernández, C. \& Aragoneses, A. (1991). El "burnout", una forma específica de estrés laboral. En G. Casal \& V. Caballo (Eds.), Manual de psicología clínica aplicada (pp. 271-280). Madrid: Siglo Veintiuno de España.

Norris, F., Murphy, A., Baker, C., Perilla, J., Rodriguez, F. \& Rodriguez, J. (2003). Epidemiology of trauma and posttraumatic stress disorder in Mexico. Journal of Abnormal Psychology, 112(4), 646-656. doi:10.1037/0021-843X.112.4.646

Órdenes, D. (2004). Prevalencia de Burnout en trabajadores del hospital Roberto del Río. Revista Chilena de Pediatría, 75(5), 449-454. doi:10.4067/S037041062004000500006

Orlando, M. \& Marshall, G. (2002). Differential item functioning in a Spanish translation of the PTSD checklist: detection and evaluation of impact. Psychological Assessment, 14(1), 50-59. doi:10.1037/1040-3590.14.1.50

Pieters, G., De Gucht, V., Joos, G. \& De Heyn, E. (2003). Frequency and impact of patient suicide on psychiatric trainees. European Psychiatry, 18(7), 345-349. doi:10.1016/j.eurpsy.2003.02.003

Quass, C. (2006). Diagnóstico de burnout y técnicas de afrontamiento al estrés en profesores universitarios de la Quinta Región de Chile. Psicoperspectivas, 5(1), 6575. Retrieved from http://www.psicoperspectivas.cl/ index.php/psicoperspectivas/article/view/35

Robinson, J., Cox, G., Bailey, E., Hetrick, S., Rodrigues, M., Fisher, S. \& Herrman, H. (2016). Social media and suicide prevention: a systematic review. Early Intervention in Psychiatry, 10(2), 103-121. doi:10.1111/eip.12229

Ruiz, A., Silva, H. \& Miranda, E. (2001). Clinical and psychometric diagnosis of depression in patients in general medicine. Revista Médica de Chile, 129(6), 627-633. doi:10.4067/S0034-98872001000600005

Ruskin, R., Sakinofsky, l., Bagby, R., Dickens, S. \& Sousa, G. (2004). Impact of patient suicide on psychiatrists and psychiatric trainees. Academic Psychiatry, 28(2), 104110. doi:10.1176/appi.ap.28.2.104

Sahraian, A., Fazelzadeh, A., Mehdizadeh, A. \& Toobaee, S. (2008). Burnout in hospital nurses: a comparison of internal, surgery, psychiatry and burns wards. International Nursing Review, 55(1), 62-67. doi:10.1111/j.14667657.2007.00582.x

Sanz, J. \& Vázquez, C. (1998). Fiabilidad, validez y datos nor- mativos del Inventario para la Depresión de Beck. Psicothema, 10(2), 303-318. Recuperado de http://www. psicothema.com/pdf/167.pdf

Scocco, P., Toffol, E., Pilotto, E. \& Pertile, R. (2012). Psychiatrists' emotional reactions to patient suicidal behavior. Journal of Psychiatric Practice, 18(2), 94-108. doi:10.1097/01.pra.0000413275.09305.d5

Takahashi, C., Chida, F., Nakamura, H., Akasaka, H., Yagi, J., Koeda, A. \& Sakai, A. (2011). The impact of inpatient suicide on psychiatric nurses and their need for support. BMC Psychiatry, 11(38), 1-8. doi:10.1186/1471244X-11-38

Tsai, A., Moran, S., Shoemaker, R. \& Bradley, J. (2012). Patient suicides in psychiatric residencies and post-vention responses: a national survey of psychiatry chief residents and program directors. Academic Psychiatry, 36(1), 34-38. doi:10.1176/appi.ap.09100186

Vera-Villarroel, P., Zych, I., Celis-Atenas, K., Córdova-Rubio, N. \& Buela-Casal, G. (2011). Chilean validation of the Posttraumatic Stress Disorder Checklist-Civilian version (PCL-C) after the earthquake on February 27, 2010. Psychological Reports, 109(1), 47-58. doi:10.2466/02.13.15.17.PR0.109.4.47-58

Vicente, B., Kohn, R., Rioseco, P., Saldivia, S., Levav, I. \& Torres, S. (2006). Lifetime and 12-month prevalence of DSMIII-R disorders in the Chile psychiatric prevalence study. American Journal of Psychiatry, 163(8), 13621370. doi:10.1176/ajp.2006.163.8.1362

Virtanen, M., Vahtera, J., Batty, G., Tuisku, K., Oksanen, T., Elovainio, M. \& Kivimäki, M. (2012). Health risk behaviors and morbidity among hospital staff-comparison across hospital ward medical specialties in a study of 21 Finnish hospitals. Scandinavian Journal of Work, Environment \& Health, 38(3), 228-237. doi:10.5271/ sjweh.3264

Warner, C., Appenzeller, G., Grieger, T., Belenkiy, S., Breitbach, J., Parker, J. \& Hoge, C. (2011). Importance of anonymity to encourage honest reporting in mental health screening after combat deployment. Archives of General Psychiatry, 68(10), 1065-1071. doi:10.1001/ archgenpsychiatry.2011.112

Witteveen, A., Bramsen, I., Twisk, J., Huizink, A., Slottje, P., Smid, T. \& Van Der Ploeg, H. (2007). Psychological distress of rescue workers eight and one-half years after professional involvement in the Amsterdam air disaster. The Journal of Nervous and Mental Disease, 195(1), 31-40. doi:10.1097/01.nmd.0000252010.19753.19

Zanarini, M., Frankenburg, F., Hennen, J. \& Silk, K. (2004). Mental health service utilization by borderline personality disorder patients and Axis II comparison subjects followed prospectively for 6 years. Journal of Clinical Psychiatry, 65(1), 28-36. Retrieved from https://www.ncbi.nlm.nih.gov/pubmed/14744165

Zlotnick, C., Johnson, J., Kohn, R., Vicente, B., Rioseco, P. \& Saldivia, S. (2006). Epidemiology of trauma, post-traumatic stress disorder (PTSD) and co-morbid disorders in Chile. Psychological Medicine, 36(11), 15231533. doi:10.1017/S0033291706008282 